\title{
Snow density climatology across the former USSR
}

\author{
X. Zhong ${ }^{1,2}$, T. Zhang ${ }^{3,4}$, and K. Wang ${ }^{3}$ \\ ${ }^{1}$ State key Laboratory of Frozen Soil Engineering, Cold and Arid Regions Environmental and Engineering Research Institute, \\ Chinese Academy of Sciences, Lanzhou 730000, China \\ ${ }^{2}$ University of Chinese Academy of Sciences, Beijing 100049, China \\ ${ }^{3}$ College of Earth and Environmental Sciences, Lanzhou University, Lanzhou 730000, China \\ ${ }^{4}$ National Snow and Ice Data Center, Cooperative Institute for Research in Environmental Sciences, University of Colorado, \\ Boulder, CO 80309-0449, USA
}

Correspondence to: T. Zhang (tjzhang@lzu.edu.cn)

Received: 16 June 2013 - Published in The Cryosphere Discuss.: 8 July 2013

Revised: 5 March 2014 - Accepted: 14 March 2014 - Published: 30 April 2014

\begin{abstract}
Snow density is one of the basic properties used to describe snow cover characteristics, and it is a key factor for linking snow depth and snow water equivalent, which are critical for water resources assessment and modeling inputs. In this study, we used long-term data from groundbased measurements to investigate snow density (bulk density) climatology and its spatiotemporal variations across the former Soviet Union (USSR) from 1966 to 2008. The results showed that the long-term monthly mean snow density was approximately $0.22 \pm 0.05 \mathrm{~g} \mathrm{~cm}^{-3}$ over the study area. The maximum and minimum monthly mean snow density was about $0.33 \mathrm{~g} \mathrm{~cm}^{-3}$ in June, and $0.14 \mathrm{~g} \mathrm{~cm}^{-3}$ in October, respectively. Maritime and ephemeral snow had the highest monthly mean snow density, while taiga snow had the lowest. The higher values of monthly snow density were mainly located in the European regions of the former USSR, on the coast of Arctic Russia, and the Kamchatka Peninsula, while the lower snow density occurred in central Siberia. Significant increasing trends of snow density from September through June of the next year were observed, however, the rate of the increase varied with different snow classes. The long-term (1966-2008) monthly and annual mean snow densities had significant decreasing trends, especially during the autumn months. Spatially, significant positive trends in monthly mean snow density lay in the southwestern areas of the former USSR in November and December and gradually expanded in Russia from February through April. Significant negative trends mainly lay in the European Russia and the southern Russia. There was a high correlation of snow den-
\end{abstract}

sity with elevation for tundra snow and snow density was highly correlated with latitude for prairie snow.

\section{Introduction}

Snow cover is a key part of the cryosphere, which is a critical component of the global climate system. Changes in snow cover serve as indicators of climate change because of its interactions and feedbacks with surface energy fluxes, moisture fluxes, hydrological processes, and atmospheric and oceanic circulations (Brown and Goodison, 1996; Sturm et al., 2002; Armstrong and Brown, 2008; King et al., 2008). There are three basic properties used to describe snow cover: snow depth, snow density, and snow water equivalent (SWE). Snow density is a key factor for linking the other two factors (Armstrong and Brown, 2008; Sturm et al., 2010). It is also one of the fundamental parameters for hydrological cycle studies, snowmelt runoff and flood forecasts, avalanche studies, model inputs and validation, and water resources assessment (Margreth, 2007; Lazar and Williams, 2008).

Every winter, the average maximum terrestrial snow cover equals nearly $47 \times 10^{6} \mathrm{~km}^{2}$, almost half of the land surface area in the Northern Hemisphere (Robinson et al., 1993; IGOS, 2007). Snow cover in Russia and Europe accounts for approximately $60 \%$ of the total snow cover area in the Northern Hemisphere (Barry et al., 1993). Majority areas of the former USSR are covered by snow up to 4 or 5 months each year. Over high Arctic Russia, snow cover starts in early September and persists through the following June; up to 
10 months each year. There are long-term and large-scale snow cover measurements and observations across the former USSR, with the first snow cover record dating back to 1881 in Latvia (Armstrong, 2001). These measurements are valuable data and information for snow cover studies.

Across the former USSR, snow cover characteristics, including snow density, are controlled by various environmental conditions. There were many studies indicating that snow cover areas had decreased significantly in Northern Hemisphere, especially in Eurasia (Robinson and Dewey, 1990; Gutzler and Rosen, 1992; Brown, 1997). However, the variations in snow depth, snow cover duration, and SWE presented regional features (Ye et al., 1998; Kitaev et al., 2005; Groisman et al., 2006; Bulygina et al., 2009). These changes in snow characteristics were closely related with climatic change (Foster et al., 1983; Groisman et al., 1994; Clark et al., 1999; Robock et al., 2003; Matsumura and Yamazaki, 2012; Cohen et al., 2012; Peng et al., 2013). Mean SWE had also been estimated from the monthly mean snow depth, snow cover extent, and an assumed monthly mean snow density over much of southern Canada for the period of 19641993 (Brown, 2000). Roebber et al. (2003) found that snowfall could be forecasted by determining snow density. Sturm et al. (2010) presented a method of obtaining SWE from snow depth by estimating the bulk density of snow.

There have been relatively few studies, however, on the climatology and the variability of snow density on a regional basis. Williams and Gold (1958) presented the variation of snow density across Canada, and the relationship between snow density and meteorological variables, particularly wind velocity and air temperature. They found that there were some difficulties in explaining the relationship between snow cover and climatic variations; however, air temperature and wind velocity could be combined into a weather index to estimate the average monthly snow density. Bilello $(1969,1984)$ classified the average snow density in four and five general categories over North America and the former USSR, respectively, basing these on air temperature and wind speed. Nomographs were developed for estimating the average seasonal snow density with multiple regression analysis, in which air temperature and wind speed were main variables. McKay and Findlay (1971) estimated the timedensity variations in 11 regions across Canada within vegetation and climatic influences. They indicated the differences of mean snow densities in vegetation regions and confirmed that there was regional homogeneity of snow density in the same vegetation region. Sturm and Holmgren (1998) analyzed time-density curves for three snow classes in Alaska and Canada, and indicated that the differences in snow density for snow classes were primarily caused by differences in the rheological properties of the snowpack. Yang et al. (1992) analyzed the spatiotemporal distribution of snow density at the source area of the Urumqi River (China), and identified average snow density was unrelated to snow depth during the stable snow cover period. However, the two terms were closely related in the unstable snow cover period. Observations indicate that there was a significant positive correlation between snow density and precipitation, snow depth, and wind velocity in Xinjiang, China (Huang et al., 2007). Dai and Che (2011) analyzed the temporal and spatial distribution of snow density across China in 1999-2008. They performed a regression analysis of snow density, precipitation, air temperature, snow depth, and wind speed, the results showed that snow depth was the primary influence on snow density in northeast and northwest China. Ma and Qin (2012) presented the spatiotemporal changes in snow density across China. The results showed that the inter-monthly variation in snow density was obvious, and the annual mean snow density was smaller over the Tibetan Plateau compared with northwest and northeast China.

Snow density is calculated from snow depth and SWE using a gravimetric method. The data can be obtained from ground meteorological stations (Bilello, 1984; Ma and Qin, 2012) or snow course sites (Bulygina et al., 2011; Bormann et al., 2013), and can be estimated from passive microwave satellite remote sensing data such as Scanning Multichannel Microwave Radiometer (SMMR) and Special Sensor Microwave/Imager (SSM/I) data. Although satellite data enrich the snow data that cannot be monitored by ground stations over remote areas, the accuracy of these data are affected by clouds, underlying surface conditions, and the inversion algorithm. In contrast, ground-based station snow data could provide for more accurate and longer time series. Therefore, ground station data set is key to better understand climatology and the variability of snow density.

The objective of this study is to provide a detailed description of snow density and to investigate the variability in snow density on a regional basis across the former USSR from 1966 to 2008. Our aim is to improve the understanding of snow density climatology and its variation over the former USSR, to analyze the probability distribution function (PDF) of snow density, and to discuss the relationships between snow density and elevation and altitude.

\section{Data and methodology}

\subsection{Snow density}

Our analyses are based on monthly mean snow density. Snow density (bulk density) data, at every 5 to 10 day intervals, were used to create a monthly mean snow density for each station.

We used two snow density data sets from 1259 snow stations in the former USSR (Table 1). One is from the Russian Research Institute for Hydrometeorological InformationWorld Data Center (RIHMI-WDC, http://meteo.ru/), which has a total of 517 meteorological stations of Russia. In this data set, measurements were performed throughout the entire period of 1966-2009. The other data set used in this study 
Table 1. Sources of snow density data.

\begin{tabular}{lrl}
\hline Data source & $\begin{array}{r}\text { Number } \\
\text { of Sites }\end{array}$ & Source \\
\hline Snow course - Russia (1) & 517 & $\begin{array}{l}\text { RIHMI-WDC, } \\
\text { http://meteo.ru/ } \\
\text { NSIDC, } \\
\text { http://nsidc.org/ }\end{array}$ \\
Snow course - USSR (2) & 1319 & 1259 \\
Unique Total & & \\
\hline
\end{tabular}

is from the National Snow and Ice Data Center (NSIDC, http://nsidc.org/), University of Colorado at Boulder. This data set includes 1319 snow course sites in the former Soviet Union, and the historical records span the period from 1966 to 2000. Both of the data sets include routine snow surveys that ran throughout the cold season (every 10 days) and during snowmelt (every 5 days). Routine snow surveys contain snow depth, snow density, ice crust thickness, thickness of saturated snow and the water layer, snow water equivalent, total water storage, snow cover features, and snow structure (Bulygina et al., 2011). Snow surveys ran across all environmental types of sites for 1 to $2 \mathrm{~km}$ in fields (open terrain) and $500 \mathrm{~m}$ in the forest. Snow depth was measured each $10 \mathrm{~m}$ in the forest and each $20 \mathrm{~m}$ in open areas; snow density and other attributes, such as snow water equivalent, ice crust thickness, fractional snow covered area, etc., were made every $100 \mathrm{~m}$ at the 500 to $1000 \mathrm{~m}$ courses and every $200 \mathrm{~m}$ at the $2000 \mathrm{~m}$ course (Bulygina et al., 2011). In the comprehensive suite of measurements, bulk density was measured by taking a snow core in a snow tube. Snow depth could be read from the scale on the side of the snow tube. Mass of the snow sample was weighed by a balance. Then bulk density was calculated by dividing weight of core by the corer volume (BC Ministry of Environment, 1981).

In the individual measurements of routine snow surveys, random and systematic errors occurred inevitably (Kuusisto, 1984), leading to underestimate or overestimate densities with snow tube (Goodison, 1978; Sturm et al., 2010). To minimize errors, quality control of meteorological data had been conducted before they were stored at the RIHMI-WDC (Veselov, 2002). We implemented the second correction of snow density according to the quality assessment criteria proposed by NSIDC: mean snow densities which exceeded the range of $0-0.6 \mathrm{~g} \mathrm{~cm}^{-3}$ were omitted. Furthermore, each site with snow density records less than 10 years were excluded, and the data outside the scope of annual mean value plus or minus three standard deviations were also omitted.

We computed the probability distribution function (PDF) of snow density measured every 5 to 10 days interval, which is the ratio between the sample data and the total snow density data. All snow densities are arranged in ascending order, and then divided equally into 30 brackets. The sample is the number of data points within a given density bracket, and the total data is the total number of data for all ground stations.

We define the period from 1 July to 30 June of the following year as a snow cover year. From September to November, new and/or fresh snow appears across the former USSR; we define this as the snow cover formation period. There is a steady and slow increase in snow density from December to February, so these months are defined as the stable period (Huang et al., 2007). March to June show obvious fluctuations in snow density, and these months are known as the unstable period (Huang et al., 2007) or melting period of snow cover. Over the whole former USSR, the longest snow cover duration was recorded on the coast of north Russia, where snow cover first appears in early September and ends in late June of the following year. Based on this, we used snow density data from September to June in our research. We collected data from 1259 unique snow course stations across the former USSR, including geographical attributes such as longitude, latitude, and elevation, during the snow cover years from 1966 to 2008. Figure 1 shows the locations of stations used in the study.

\subsection{Snow classes}

Sturm et al. (1995) categorized the world's seasonal snow cover into six classes (tundra, taiga, alpine, maritime, prairie, and ephemeral snow) based on their physical properties, and then empirically related these to climate conditions using three variables (precipitation, wind, and air temperature). A vegetation proxy was used for wind data: tall vegetation equaled low wind, and short vegetation equaled high wind.

In our study, we investigated changes in snow density over each snow class. Based on the seasonal snow cover classification system proposed by Sturm et al. (1995), the Global Seasonal Snow Classification System data set is used (Fig. 1). Snow classes data over the former USSR were obtained from the National Center for Atmospheric ResearchEarth Observing Laboratory [NCAR/EOL], (http://data.eol. ucar.edu/). The snow classification data are formatted into an array of integers, each value representing a $0.5^{\circ}$ latitude by $0.5^{\circ}$ longitude cell. The total snow cover extent in the former USSR is approximately $21.34 \times 10^{6} \mathrm{~km}^{2}$, of which tundra, taiga, and prairie snow account for about $87 \%$ (Fig. 2).

\section{Results}

\subsection{Climatology of snow density}

The maximum mean snow density was about $0.44 \mathrm{~g} \mathrm{~cm}^{-3}$, and the minimum value was $0.09 \mathrm{~g} \mathrm{~cm}^{-3}$ (Fig. 3). Overall, snow density increased across the former USSR, at a rate of about $0.0008 \mathrm{~g} \mathrm{~cm}^{-3} \mathrm{day}^{-1}$. In the late September, there was higher snow density on some days due to fresh snow melting with the high air temperature. Mean snow density gradually increased from October to June. There was a fluctuation of 


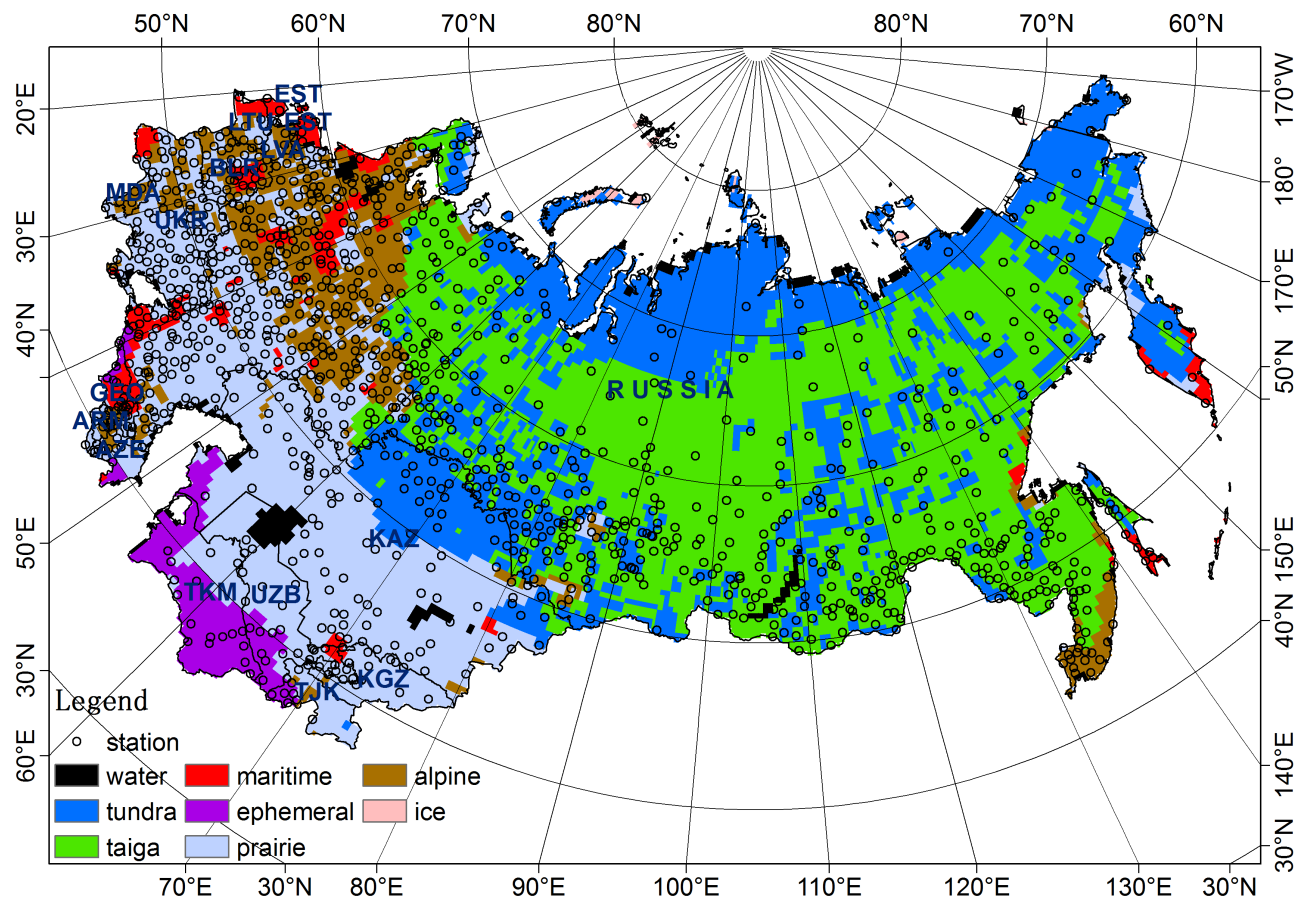

Fig. 1. Geographical locations and distribution of snow course stations and snow classes across the former USSR.

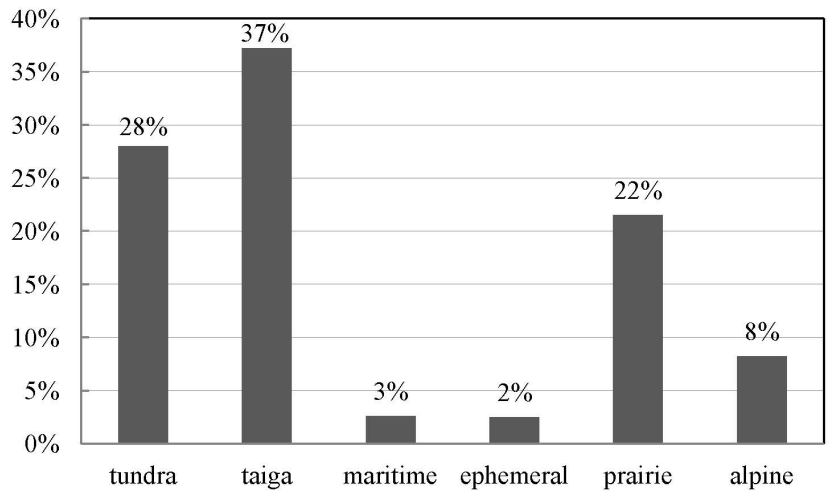

Fig. 2. Percentage of snow cover area for six snow classes across the former USSR.

snow density in February: increasing on some days because of snowmelt, while decreasing on other days which were affected by new snowfall. From May to June, mean snow density increased sharply that was caused by snowmelt as air temperature rises.

There is an obvious monthly characteristic in snow density across the former USSR (Fig. 4 and in the Supplement with dynamic diagram). The highest values of monthly snow density were mainly located in the European part of the former USSR, on the coast of Arctic Russia, and the Kamchatka Peninsula. In contrast, the lowest snow density was found in central Siberia. There were few ground stations with snow in September, and sites were mainly located in Russia. Most of the monthly snow density values were less than $0.20 \mathrm{~g} \mathrm{~cm}^{-3}$ but the sites with values ranging from 0.20 to $0.40 \mathrm{~g} \mathrm{~cm}^{-3}$ were located in the northeast of the Russian Far East, on the coast of Arctic Russia, and some western areas of the former USSR. From October to November, the number of stations with snow gradually increased, and monthly snow density became higher. Most snow density mainly ranged from $0.10 \mathrm{~g} \mathrm{~cm}^{-3}$ to $0.20 \mathrm{~g} \mathrm{~cm}^{-3}$. The stations with snow density greater than $0.20 \mathrm{~g} \mathrm{~cm}^{-3}$ appeared in the European areas, on the coast of northern Russia and in the Russian Far East.

In the stable period of snow cover, snow density was greater than in autumn months. Most monthly snow density measurements ranged between $0.15 \mathrm{~g} \mathrm{~cm}^{-3}$ and $0.30 \mathrm{~g} \mathrm{~cm}^{-3}$; they were higher in some western regions of the former USSR and on the coast of Arctic Russia $\left(>0.30 \mathrm{~g} \mathrm{~cm}^{-3}\right)$.

High temperature led to snow melt, which increased the snow density during the unstable period. Monthly snow density ranged between $0.20 \mathrm{~g} \mathrm{~cm}^{-3}$ and $0.35 \mathrm{~g} \mathrm{~cm}^{-3}$ in March, with values above $0.35 \mathrm{~g} \mathrm{~cm}^{-3}$ in most areas of European Russia and on the coast of northern Russia, while snow density values were low in central Siberia and in some regions of the Russian Far East (around $0.20 \mathrm{~g} \mathrm{~cm}^{-3}$ ). In April, monthly snow density continued to increase, with most values ranging from $0.25 \mathrm{~g} \mathrm{~cm}^{-3}$ to $0.40 \mathrm{~g} \mathrm{~cm}^{-3}$. Compared with March, the number of sites with snow density $>0.40 \mathrm{~g} \mathrm{~cm}^{-3}$ increased, with a range was 0.20 to $0.30 \mathrm{~g} \mathrm{~cm}^{-3}$ in central Siberia. In May, there were significantly less sites with snow, and these were mainly located in Russia. There were obviously increase in monthly snow density in Russia; however, snow 


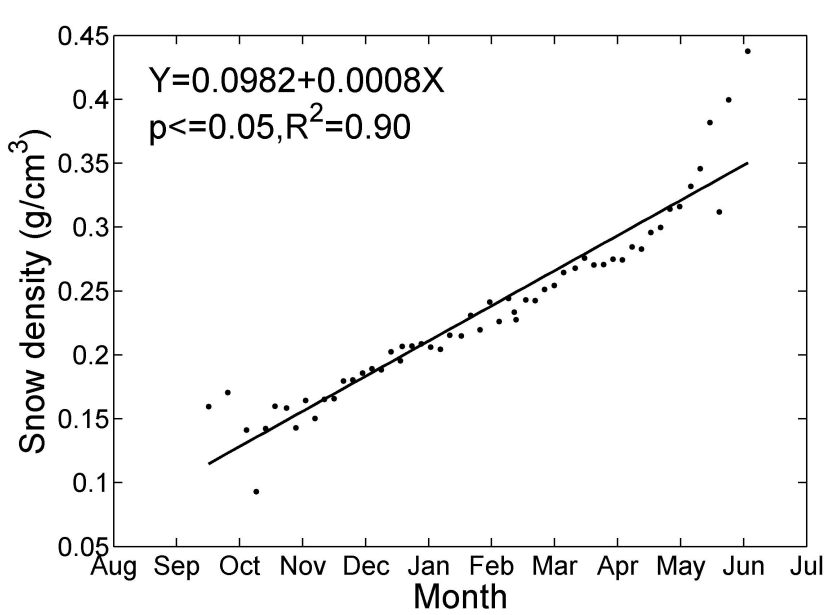

Fig. 3. Mean snow density measured at 5-10 days intervals at all stations across the former USSR from September to June. Dots represent the computed mean snow density of all stations. The thick line represents a linear regression trend. In the equation, $y$ stands for snow density in $\mathrm{g} \mathrm{cm}^{-3}$, and $x$ for date. We defined September 1 as the first day in a snow cover year, therefore, $x$ ranged from 1 (1 September) to 304 (30 June) in the simulation of snow density. $p$ is the confidence level for the coefficient estimates, and $R^{2}$ is the goodness of fit coefficient.

density decreased in some areas of the southwestern portion of the former USSR due to fresh snow. A few stations reported data in June over the northern areas of Russia, the south of central Siberia, the northeast of the Russian Far East. The maximum monthly snow density value across the 10 month study period ranged between $0.30 \mathrm{~g} \mathrm{~cm}^{-3}$ and $0.50 \mathrm{~g} \mathrm{~cm}^{-3}$.

Snow densities were consistent with the distributions of snow depth from September to March, especially in the western areas across the former USSR. They increased with increasing depths. In the melting period, snow density increased due to higher air temperature. However, snow densities did not increase more quickly with times in eastern Russia. On the one hand, most areas were taiga snow where was cold led to the density trends to plateau. In the eastern arctic and sub-arctic, most sites with snow survey in forested environments (Bulygina et al., 2011; Fig. 2b). Snow cover under the protection of trees in forests is less affected by wind speed or solar radiation compared with that in open fields. The variations in snow depth were not significantly with time in these areas. Therefore, snow density increased slowly. On the other hand, the arctic coast snow depths had remained stable and low air temperature resulting in slowly increase in monthly mean snow densities.

\subsection{Variability of snow density}

There were significant monthly and seasonal changes in snow density (Fig. 5, Table 2). The average snow density was approximately $0.22 \pm 0.05 \mathrm{~g} \mathrm{~cm}^{-3} \mathrm{month}^{-1}$. The maximum long-term monthly mean snow density of about $0.33 \mathrm{~g} \mathrm{~cm}^{-3}$ occurred in June during snowmelt season, while the minimum was about $0.14 \mathrm{~g} \mathrm{~cm}^{-3}$ in October, with mostly fresh snow. The largest standard deviation of snow density from its long-term monthly mean was about $0.09 \mathrm{~g} \mathrm{~cm}^{-3}$ in June, when snow was melting across the entire study area. The minimum standard deviation of about $0.04 \mathrm{~g} \mathrm{~cm}^{-3}$ occurred in winter months, indicating relatively uniform snow density during the stable period across the regions. There is a general trend of increasing monthly mean snow density from September through June of the next year (Fig. 5) with an average rate of about $0.0210 \mathrm{~g} \mathrm{~cm}^{-3}$ per month, which is basically consistent with the daily increase rate as shown in Fig. 3. From September through November, monthly mean snow density was lower than $0.16 \mathrm{~g} \mathrm{~cm}^{-3}$, indicating new and/or fresh snow across the region. From December to February, monthly snow density increased gradually from $0.18 \mathrm{~g} \mathrm{~cm}^{-3}$ in December to $0.22 \mathrm{~g} \mathrm{~cm}^{-3}$ in February. Snow density was influenced by cold temperature and wind, which compacted the snow layer and caused high snow density. In the spring months (the unstable period), monthly mean snow density increased rapidly. This is mainly because snow began to melt with increasing air temperature, and the snowmelt water infiltration into deeper layer of snow cover, leading to a sharp increase in snow density.

For the six snow classes, the maximum longterm monthly mean snow density was measured in maritime $\left(0.25 \pm 0.05 \mathrm{~g} \mathrm{~cm}^{-3}\right)$ and ephemeral snow $\left(0.25 \pm 0.09 \mathrm{~g} \mathrm{~cm}^{-3}\right)$, and the minimum value of $0.20 \pm 0.04 \mathrm{~g} \mathrm{~cm}^{-3}$ per month was seen in taiga snow. The long-term monthly mean snow density of the six snow classes also changed significantly with the seasons (Fig. 6). The variation in monthly snow density for tundra snow and taiga snow were consistent with the trend across all data. This was mainly because the areas of tundra snow and taiga snow accounted for more than $60 \%$ of the total area across the former USSR, and the sample data points of the two snow classes accounted for about $40 \%$ of all data points. During the initial snow cover period (SeptemberNovember), monthly snow density of the two snow classes were lower compared with other months. The minimum long-term monthly snow density appeared in October for tundra snow $\left(0.14 \mathrm{~g} \mathrm{~cm}^{-3}\right)$ and taiga snow $\left(0.13 \mathrm{~g} \mathrm{~cm}^{-3}\right)$. With the increase in the amount of snow cover and snow depth, and low solar radiation in the winter months, snow layers were gradually compacted by overlying snow and strong winds, and thus snow density increased slightly. Then, monthly snow density increased significantly from March to June. This may be attributed to the higher air temperatures during this period, causing snowmelt. The maximum long-term monthly mean snow densities of $0.34 \mathrm{~g} \mathrm{~cm}^{-3}$ for tundra snow and $0.33 \mathrm{~g} \mathrm{~cm}^{-3}$ for taiga snow appeared in June. The maximum standard deviation of snow density from its long-term monthly mean occurred in June for tundra $\left(0.07 \mathrm{~g} \mathrm{~cm}^{-3}\right)$ and taiga snow $\left(0.08 \mathrm{~g} \mathrm{~cm}^{-3}\right)$. In 

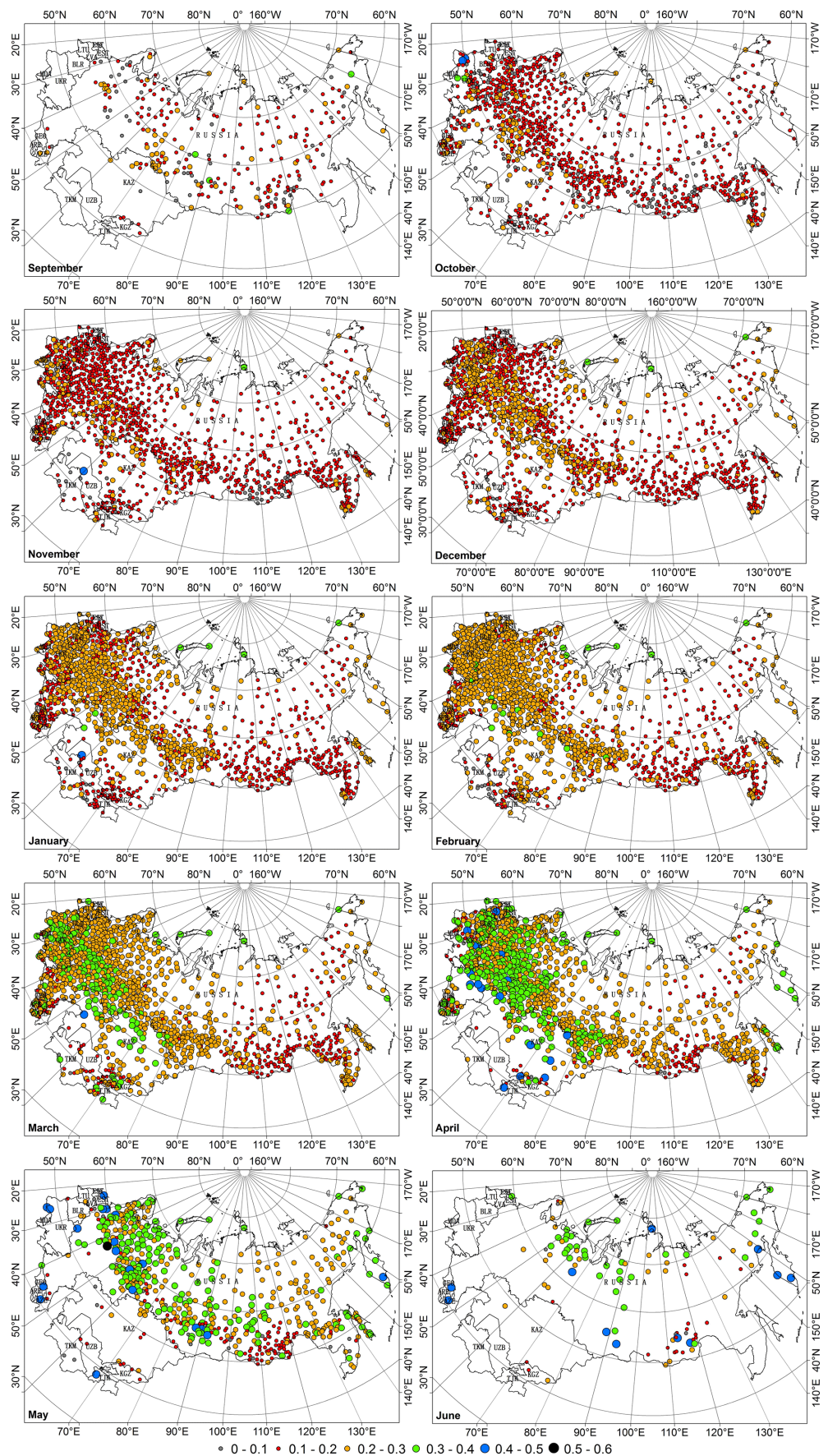

Fig. 4. Spatial distribution of monthly mean snow density for each station during 1966-2008 across the former USSR. Dots represent the value of the monthly mean snow density $\left(\mathrm{g} \mathrm{cm}^{-3}\right)$ of each station.

contrast, the minimum standard deviation $\left(0.03 \mathrm{~g} \mathrm{~cm}^{-3}\right)$ was found in winter months, indicating that snow density of mature snow was relatively steady in these sites.

The trends of monthly mean snow density for maritime, prairie, and alpine snow had similar variability: there was a significant increase in monthly snow density as the season progressed from September to June. The maximum long- term monthly snow density was observed in May or June, and the minimum value occurred in autumn. There were no snow density records for ephemeral snow in September and June; its maximum was about $0.49 \mathrm{~g} \mathrm{~cm}^{-3}$ in May, with a minimum of $0.15 \mathrm{~g} \mathrm{~cm}^{-3}$ in October, while there was a fluctuation in monthly mean snow density for ephemeral snow. From September to February, monthly snow density 
Table 2. Monthly mean snow density of each snow class $\left(\mathrm{g} \mathrm{cm}^{-3}\right)$.

\begin{tabular}{lcccrcrr}
\hline & Tundra & Taiga & Maritime & Ephemeral & Prairie & Alpine & All \\
\hline Sep & $0.16 \pm 0.07$ & $0.14 \pm 0.05$ & $0.18 \pm 0.05$ & NaN & $0.13 \pm 0.04$ & $0.16 \pm 0.07$ & $0.15 \pm 0.06$ \\
Oct & $0.14 \pm 0.04$ & $0.13 \pm 0.04$ & $0.15 \pm 0.05$ & $0.15 \pm 0.13$ & $0.16 \pm 0.05$ & $0.14 \pm 0.05$ & $0.14 \pm 0.04$ \\
Nov & $0.16 \pm 0.04$ & $0.15 \pm 0.03$ & $0.17 \pm 0.05$ & $0.20 \pm 0.14$ & $0.17 \pm 0.05$ & $0.16 \pm 0.04$ & $0.16 \pm 0.04$ \\
Dec & $0.18 \pm 0.03$ & $0.17 \pm 0.03$ & $0.19 \pm 0.05$ & $0.18 \pm 0.06$ & $0.19 \pm 0.05$ & $0.19 \pm 0.04$ & $0.18 \pm 0.04$ \\
Jan & $0.20 \pm 0.03$ & $0.18 \pm 0.03$ & $0.21 \pm 0.05$ & $0.19 \pm 0.08$ & $0.21 \pm 0.05$ & $0.21 \pm 0.04$ & $0.20 \pm 0.04$ \\
Feb & $0.21 \pm 0.03$ & $0.19 \pm 0.03$ & $0.24 \pm 0.05$ & $0.23 \pm 0.09$ & $0.23 \pm 0.05$ & $0.23 \pm 0.04$ & $0.22 \pm 0.04$ \\
Mar & $0.23 \pm 0.03$ & $0.21 \pm 0.03$ & $0.27 \pm 0.05$ & $0.22 \pm 0.09$ & $0.26 \pm 0.06$ & $0.26 \pm 0.04$ & $0.24 \pm 0.05$ \\
Apr & $0.26 \pm 0.05$ & $0.24 \pm 0.04$ & $0.32 \pm 0.05$ & $0.35 \pm 0.14$ & $0.30 \pm 0.07$ & $0.30 \pm 0.06$ & $0.28 \pm 0.06$ \\
May & $0.27 \pm 0.05$ & $0.28 \pm 0.06$ & $0.36 \pm 0.04$ & $0.49 \pm 0.03$ & $0.32 \pm 0.06$ & $0.32 \pm 0.06$ & $0.29 \pm 0.06$ \\
Jun & $0.34 \pm 0.07$ & $0.33 \pm 0.08$ & $0.47 \pm 0.06$ & NaN & NaN & NaN & $0.33 \pm 0.09$ \\
Mean & $0.22 \pm 0.04$ & $0.20 \pm 0.04$ & $0.25 \pm 0.05$ & $0.25 \pm 0.09$ & $0.22 \pm 0.06$ & $0.22 \pm 0.05$ & $0.22 \pm 0.05$ \\
\hline
\end{tabular}

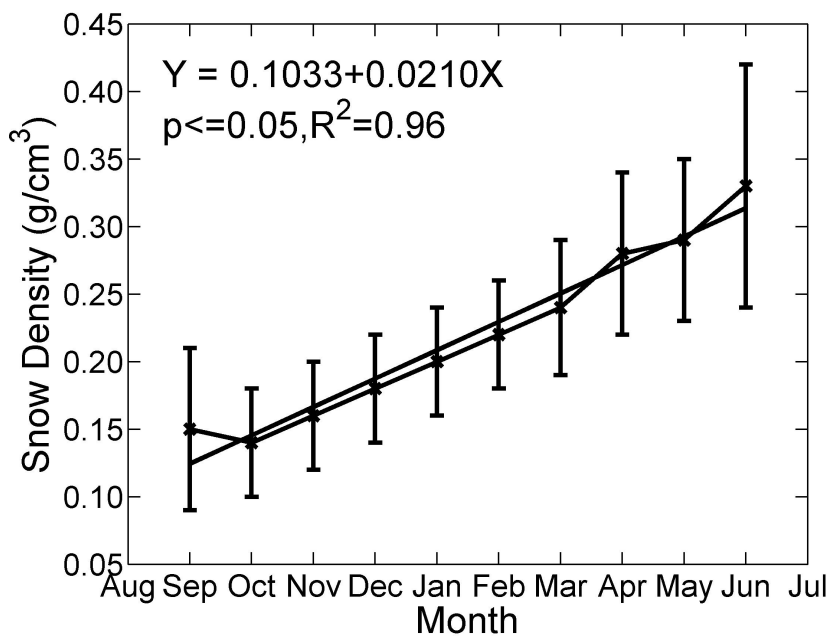

Fig. 5. Monthly mean snow density at 1259 stations across the former USSR from 1966 to 2008. The asterisk is the computed monthly mean snow density; the error bar represents one standard deviation from the mean over the entire period. The thick line is a linear regression trend. In the equation, $y$ stands for snow density in $\mathrm{g} \mathrm{cm}^{-3}$, and $x$ for time in months (from September to June). September was the first month in a snow cover year, therefore, $x$ ranged from month 1 (September) to month 10 (June) in the simulation of monthly snow density. $p$ is the confidence level for the coefficient estimates, and $R^{2}$ is the goodness of fit coefficient.

increased because of snow densification processes due to snow thickness increase and wind compact. However, there was a decrease in snow density in March, which was caused by more new spring snow over the old snow cover. Snow density for ephemeral snow increased significantly during April to May with higher air temperature.

The long-term maximum annual mean snow density across the former USSR from 1966 to 2008 was about $0.24 \mathrm{~g} \mathrm{~cm}^{-3}$ in 1973 and the minimum was about $0.20 \mathrm{~g} \mathrm{~cm}^{-3}$ in 2000 (Fig. 7). From the mid-1960s to the late 1990 s, there was a slow decrease in annual mean snow density; decreasing by about $0.01 \mathrm{~g} \mathrm{~cm}^{-3}$ at a rate of about $-0.0004 \mathrm{~g} \mathrm{~cm}^{-3}$ per year. There was a sudden drop in snow density in the 2000s (Fig. 7), while there had been no changes in the observation procedures during the period (Bulygina et al., 2011). Based on data and information from the long-term annual variation of monthly snow density, there were significant decreases in snow densities from February through April during the 2000s (Fig. 8 February, March, April), which may lead to an overall snow density decrease. Further investigation shows that there were abrupt increases in snowfall of the three months from the late 1990s to the early 2000s. The fresh snow accumulated was approximate $5-6 \mathrm{~cm}$ more than the long-term (1971-2000) mean. Furthermore, wind speed over the same period was significantly reduced comparing with its long-term mean (Loginov and Volchek, 2006; Speranskaya, 2011; Bulygina et al., 2012). Therefore, abrupt increase in snowfall and significant decrease in wind speed since the early 2000s may be the major reasons to explain sharp decrease in snow densities during the 2000s. However, there may be other reasons to explain the significant decrease in snow density; therefore, further investigations are required. After the early 2000 s, although annual mean snow density increased at a rate of $0.0013 \mathrm{~g} \mathrm{~cm}^{-3} \mathrm{yr}^{-1}$, it was far less than its long-term mean value.

There were annual decreasing trends of monthly snow density from September to May, and the trends were statistically significant at $p<0.05$ (Fig. 8). The maximum decrease rate was about $0.0013 \mathrm{~g} \mathrm{~cm}^{-3} \mathrm{yr}^{-1}$ in October, and the minimum appeared in April and May, with a rate of $-0.0002 \mathrm{~g} \mathrm{~cm}^{-3} \mathrm{yr}^{-1}$. Compared with other months, the $y$ axis scale is larger in September. In the snow cover formation period, new snow was not stable on the ground, and snow melted with high temperature which caused large interannual variation of snow density in September. In addition, the delay in the onset of snowfall was one of the reasons for larger variation in snow density. Compared with the autumn months, the inter-annual variability of snow density significantly decreased from December to May, and was lower than $0.001 \mathrm{~g} \mathrm{~cm}^{-3} \mathrm{yr}^{-1}$ 

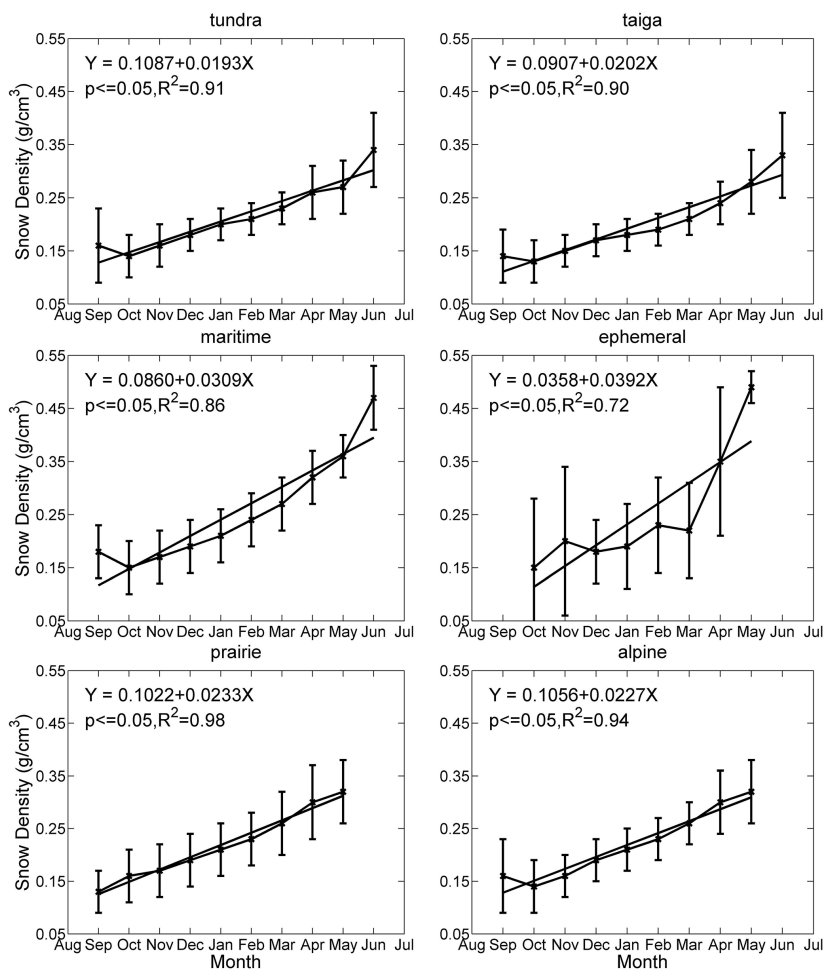

Fig. 6. Monthly mean snow density for tundra, taiga, maritime, ephemeral, prairie, and alpine snow. The asterisk is the computed monthly mean snow density; the error bar represents one standard deviation from the mean over the entire period. The thick line is a linear regression trend. In the equation, $y$ stands for snow density in $\mathrm{g} \mathrm{cm}^{-3}$, and $x$ for time in months (from September to June). September was the first month in a snow cover year, therefore, $x$ ranged from month 1 (September) to month 10 (June) in the simulation of monthly snow density. $p$ is the confidence level for the coefficient estimates, and $R^{2}$ is the goodness of fit coefficient.

For the period from the mid-1960s to the early 1980s, the annual mean snow densities from September to January and May were generally above its long-term mean value. However, hereafter, snow densities were below their long-term mean value. From 1966 to the late 1990s, the annual mean snow density fluctuated in February, March and April. While due to new snow increased, snow densities showed significant decreases from the late 1990s to the early 2000s, which caused annual snow density sudden decrease during this period.

Figure 9 shows the spatial distributions of linear trend coefficients of monthly mean snow density for each station during the period of 1966-2008. The significant trends in changes of snow density were mainly located in the areas between 50 and $60^{\circ} \mathrm{N}$ and the southwestern areas of the former USSR. In November, the positive trends were mainly presented in the southwest of the former USSR. The decreasing trends lay in most regions of the European Russia, the south of western and central Siberia. The maximum

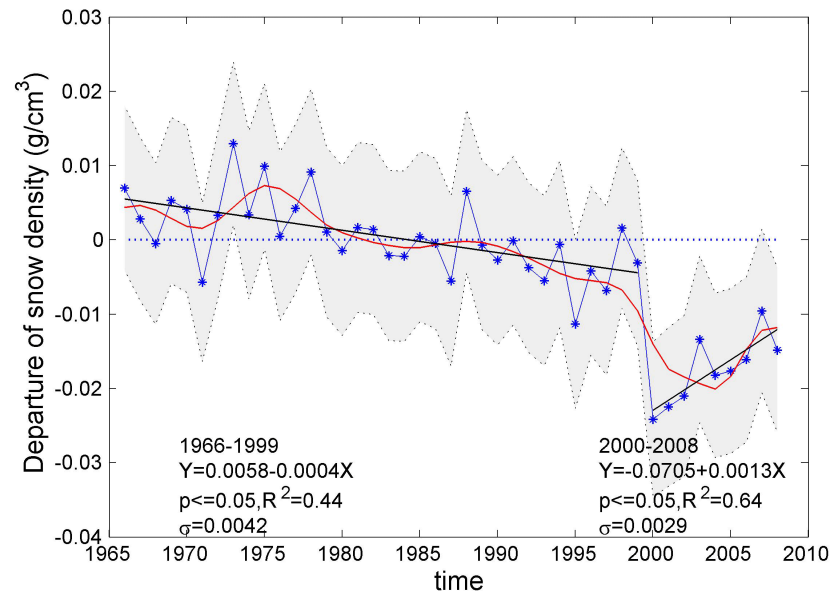

Fig. 7. Variation of annual mean snow density across the former USSR from 1966 through 2008, with respect to the 1971-2000 mean. The thin solid line with asterisk is the computed annual mean of snow density; the solid curve represents the trend of wavelet analysis; the gray area represents one standard deviation from the 19712000 mean for each year; the thick solid line of change trends in snow density with time, where $y$ represents snow density in $\mathrm{g} \mathrm{cm}^{-3}$ and $x$ represents time in snow cover years, 1966 was the first snow cover year, therefore, $x$ ranged from year 1 (1966) to year 43 (2008) in the simulation of annual mean snow density. $p$ is the confidence level for the coefficient estimates, $R^{2}$ is the goodness of fit coefficient, and $\sigma$ is one standard deviation.

values of increasing and decreasing linear trends were about $0.008 \mathrm{~g} \mathrm{~cm}^{-3} \mathrm{yr}^{-1}$ and $-0.010 \mathrm{~g} \mathrm{~cm}^{-3} \mathrm{yr}^{-1}$, respectively.

During winter months, the positive trends gradually reduced in the southwest of the former USSR, but they were found in some regions of the European Russia, and the southern areas of Russia. The most significant increases were found on the coast of the Arctic Russia. In contrast, the negative trends in snow density decreased slightly and the maximum decrease lay in the northwest of the former USSR.

In the spring months (March and April), there were significant increasing trends in monthly snow density, and they were found in most areas of Russia. The decreasing trends mainly lay in the southwest of the European Russia and the east of Kazakhstan in March, and some regions of the southern Russia in April. The stations with snow density records decreased obviously in April and were mostly located in Russia.

\subsection{Probability distribution function of snow density}

The probability distribution function (PDF) can be used to indicate the distribution of snow density occurrence and changes in distribution of snow density with time. We calculated the PDF of snow density from 0.01 to $0.60 \mathrm{~g} \mathrm{~cm}^{-3}$, and the result showed that snow density exhibited a nearly symmetrical distribution. Then, in order to verify the density distribution was a normal distribution, we simulated the normal 

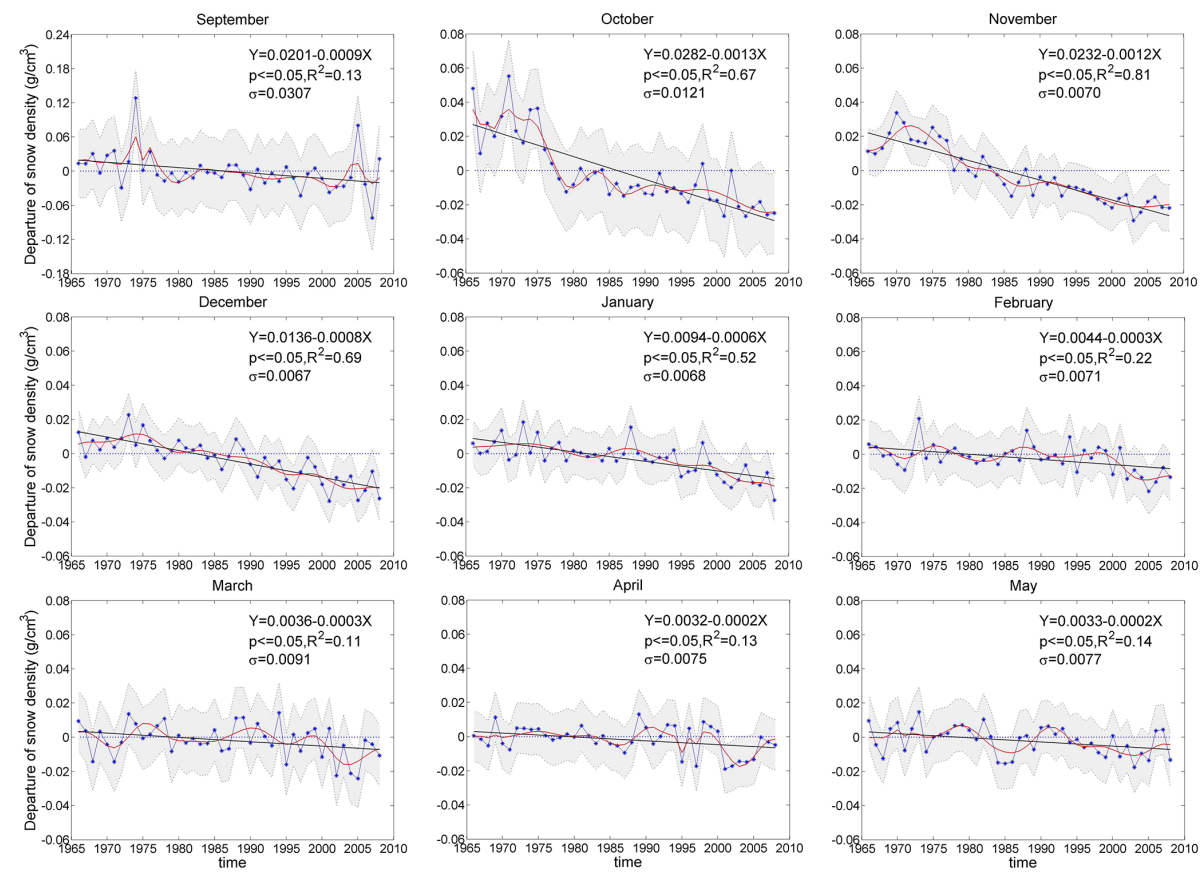

Fig. 8. The annual variation of monthly snow density across the former USSR from 1966 through 2008, with respect to the 1971-2000 mean. The thin solid line with asterisk is the computed annual mean of snow density; the solid curve represents the trend of wavelet analysis; the gray area represents one standard deviation from the 1971-2000 mean for each year; the thick solid line of change trends in snow density with time. $y$ represents snow density in $\mathrm{g} \mathrm{cm}^{-3}$ and $x$ represents time in snow cover years, 1966 was the first snow cover year, therefore, $x$ ranged from year 1 (1966) to year 43 (2008) in the simulation of annual mean snow density. $p$ is the confidence level for the coefficient estimates, $R^{2}$ is the goodness of fit coefficient, and $\sigma$ is one standard deviation. The $y$ axis scale is larger in September, which is three times as large as the scales in other months.

distribution of snow density with an approximate statistical method: all snow density data values were ranged by ascending order and were divided into 30 brackets, then specific data points were selected from observations to fit the probability distribution, such as the midpoint and the computed mean of each interval, and the approximate solutions were obtained. The fitting result showed that the PDF of snow density fit with the normal distribution.

Mean snow density from all data was $0.23 \mathrm{~g} \mathrm{~cm}^{-3}$, with a standard deviation of about $0.07 \mathrm{~g} \mathrm{~cm}^{-3}$ (Fig. 10). The peak PDF was 0.12 , which accounted for about $12 \%$ of the total number of snow density measurements from all snow course stations. The corresponding snow density ranged from 0.18 to $0.20 \mathrm{~g} \mathrm{~cm}^{-3}$. The credibility intervals indicated that $95 \%$ of all snow density values lay between $0.11 \mathrm{~g} \mathrm{~cm}^{-3}$ and $0.38 \mathrm{~g} \mathrm{~cm}^{-3}$.

There were significant similarities in the spectrum distribution, mean value, peak PDF, and credibility intervals of snow density for tundra and taiga snow (Fig. 11). The mean snow densities of tundra and taiga snow classes was about $0.22 \mathrm{~g} \mathrm{~cm}^{-3}$ and $0.21 \mathrm{~g} \mathrm{~cm}^{-3}$, respectively, which were smaller than the value of all snow densities. The range was about 0.18 to $0.20 \mathrm{~g} \mathrm{~cm}^{-3}$ at the maximum frequency distribution of snow density, the same as the result for all data, accounted for $14 \%$. The range $(2.5-97.5 \%$ of snow den- sity) was $0.11 \mathrm{~g} \mathrm{~cm}^{-3}$ to $0.36 \mathrm{~g} \mathrm{~cm}^{-3}$ for tundra snow, and $0.10 \mathrm{~g} \mathrm{~cm}^{-3}$ to $0.35 \mathrm{~g} \mathrm{~cm}^{-3}$ for taiga snow. Compared with tundra and taiga snow, maritime, prairie, and alpine snow had a wider range of the snow density distribution, and the parameter values were greater. These snow types had the same mean of $0.24 \mathrm{~g} \mathrm{~cm}^{-3}$ and standard deviation was $0.07 \mathrm{~g} \mathrm{~cm}^{-3}$. The proportion of snow density at the peak PDF declined, which accounted for $12 \%, 11 \%$, and $13 \%$, of these three snow types. At the $95 \%$ confidence interval, there was no change in snow density at the $2.5 \%$ percentile. However, significant differences were present at the $97.5 \%$ percentile, and snow density increased by about $0.03-0.05 \mathrm{~g} \mathrm{~cm}^{-3}$ compared with taiga snow. The widest range of snow density appeared in ephemeral snow, and the frequency distribution was not concentrated. Although we found the lowest mean snow density $\left(0.20 \mathrm{~g} \mathrm{~cm}^{-3}\right)$ in ephemeral snow, the standard deviation $\left(0.09 \mathrm{~g} \mathrm{~cm}^{-3}\right)$ was greatest among the six snow classes. This was because of the large difference in snow density at each station for ephemeral snow.

Figure 12 represents the frequency distribution of monthly snow density across the former USSR. There were significant normal distributions of snow density in months except September and June, and the distribution of snow density gradually widened with months. We found an increasing trend in the mean snow density from September to June, 

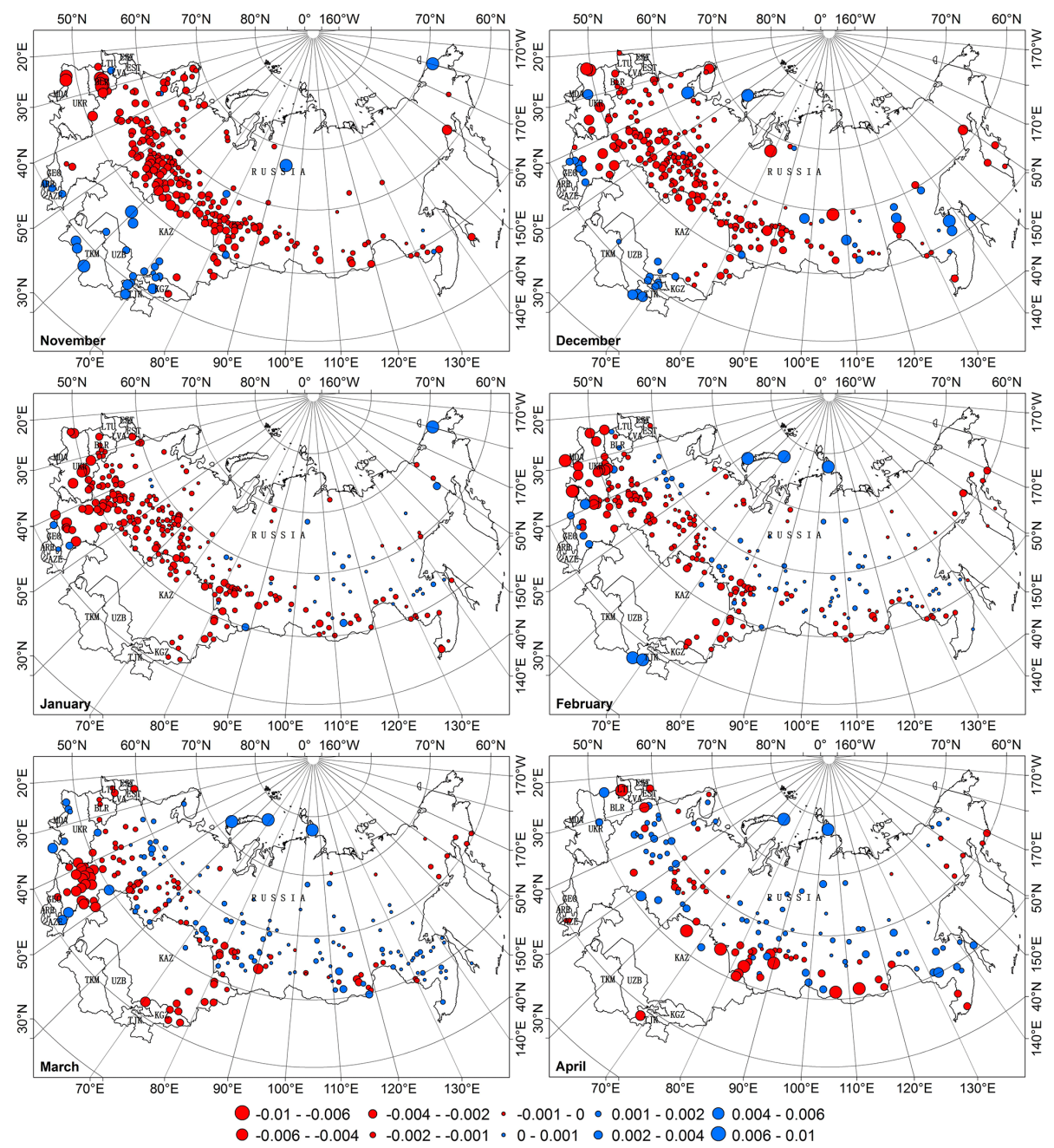

Fig. 9. Spatial distributions of linear trend coefficients $\left(\mathrm{g} \mathrm{cm}^{-3} \mathrm{yr}^{-1}\right)$ of monthly mean snow density (from November to April) for each station during 1966-2008. The rates of changes in monthly mean snow density are statistically significant at $p<0.05$ significant level. Red circles represent decreasing trends while blue circles denote increasing trends in snow density.

increased by approximately $0.20 \mathrm{~g} \mathrm{~cm}^{-3}$. The largest proportion of snow density in the distribution was $17-18 \%$ from September to October, and the corresponding snow density range was $0.09-0.11 \mathrm{~g} \mathrm{~cm}^{-3}$ and $0.10-0.12 \mathrm{~g} \mathrm{~cm}^{-3}$, respectively. The proportion was maintained at the range of 15 $16 \%$ in winter months, and snow density at the peak PDF increased to between 0.18 and $0.22 \mathrm{~g} \mathrm{~cm}^{-3}$, almost double the range in autumn, which was probably caused by low temperatures and strong winds. After March, snow density increased significantly and the density distribution was more dispersed. The value of the largest percentage of snow density only accounted for $10 \%$ of all density in June, but ranged from 0.35 to $0.37 \mathrm{~g} \mathrm{~cm}^{-3}$. The $95 \%$ confidence interval was also expanded with the increase in snow density. The range $(2.5-97.5 \%)$ was about 0.06 to $0.30 \mathrm{~g} \mathrm{~cm}^{-3}$ in September; however, $95 \%$ of the data lay between 0.10 and $0.51 \mathrm{~g} \mathrm{~cm}^{-3}$ in June, an increase of approximately $70 \%$.

\subsection{Changes in snow density with elevation and latitude}

In order to analyze the relationships between snow density and geographical factors, we conducted linear regression analysis of snow density with elevation and latitude. The elevation of the study sites ranged between -24 and $2077 \mathrm{~m}$. There was an anti-correlation between them, that is, snow density generally decreases with increase of elevation (Fig. 13). The rate of snow density decrease was about $0.004 \mathrm{~g} \mathrm{~cm}^{-3}$ per $100 \mathrm{~m}$ increase in elevation. However, it has to be mentioned that the majority of snow density measurements were conducted at elevations below $500 \mathrm{~m}$ a.s.1. To better understand the relationship between snow density and elevation, much more measurements are needed at higher elevations.

For each snow classes, snow density also showed a decline trend with elevation (Fig. 14). However, the rate of snow density decrease for each snow class was different. 


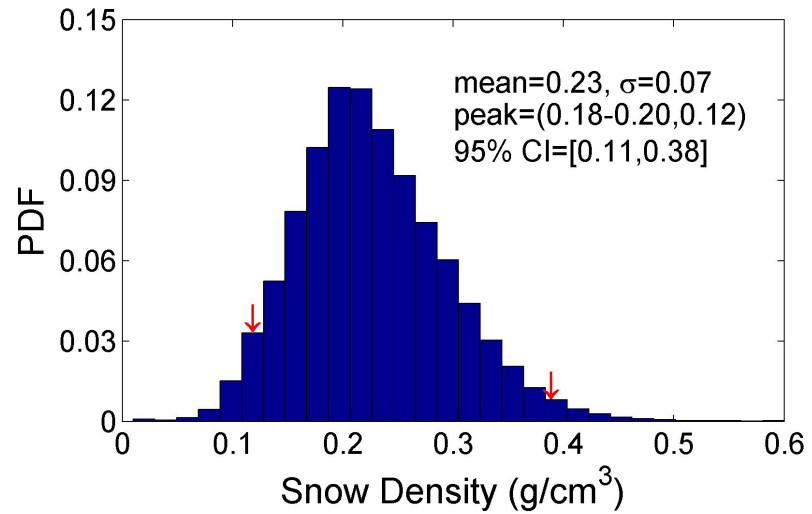

Fig. 10. Probability distribution function (PDF) of snow density for all data measured every 5 to 10 days interval. The bar is PDF of snow density; the down arrows represent the bracket $2.5 \%$ and $97.5 \%$ spectrum distribution of snow density. Mean and $\sigma$ represent the calculated mean and standard deviation of all snow density $\left(\mathrm{g} \mathrm{cm}^{-3}\right)$, respectively. Peak stands for the peak PDF of snow density (right) and the corresponding snow density (left); $95 \% \mathrm{CI}$ represents the range of snow density at $95 \%$ credibility interval; CI is the abbreviation for "credibility interval".
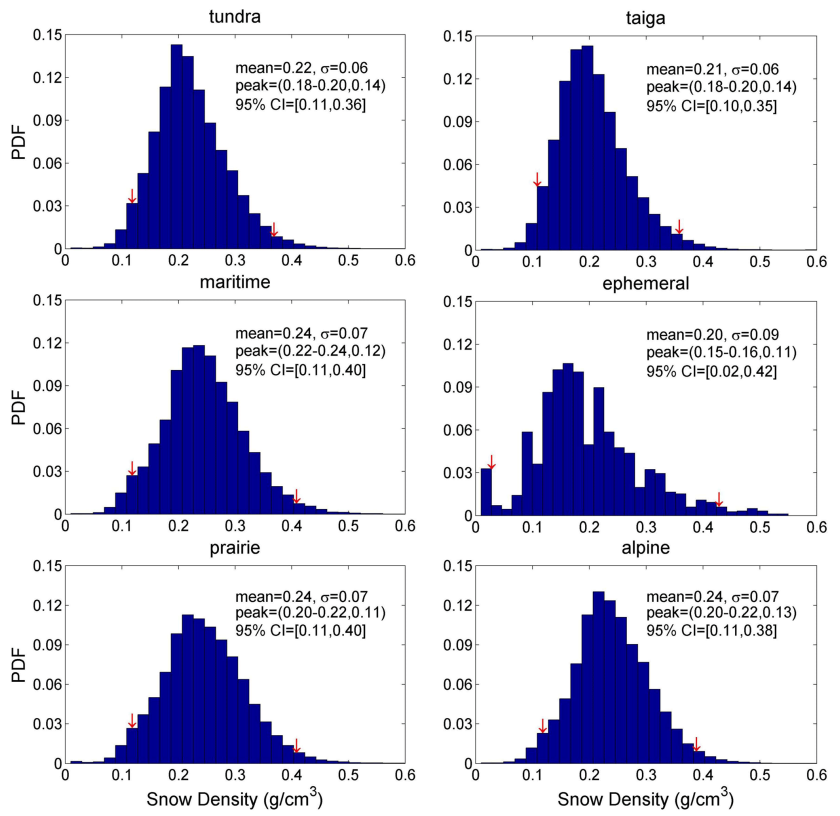

Fig. 11. PDF of snow density for tundra, taiga, maritime, ephemeral, prairie, and alpine snow. The bar is PDF of snow density; the down arrows represent the bracket $2.5 \%$ and $97.5 \%$ spectrum distribution of snow density. Mean and $\sigma$ represent the calculated mean and standard deviation of all snow density $\left(\mathrm{g} \mathrm{cm}^{-3}\right)$, respectively. Peak stands for the peak PDF of snow density (right) and the corresponding snow density (left); $95 \%$ CI represents the range of snow density at $95 \%$ credibility interval; $\mathrm{CI}$ is the abbreviation for "credibility interval".

With every $100 \mathrm{~m}$ increase in elevation, snow density de-
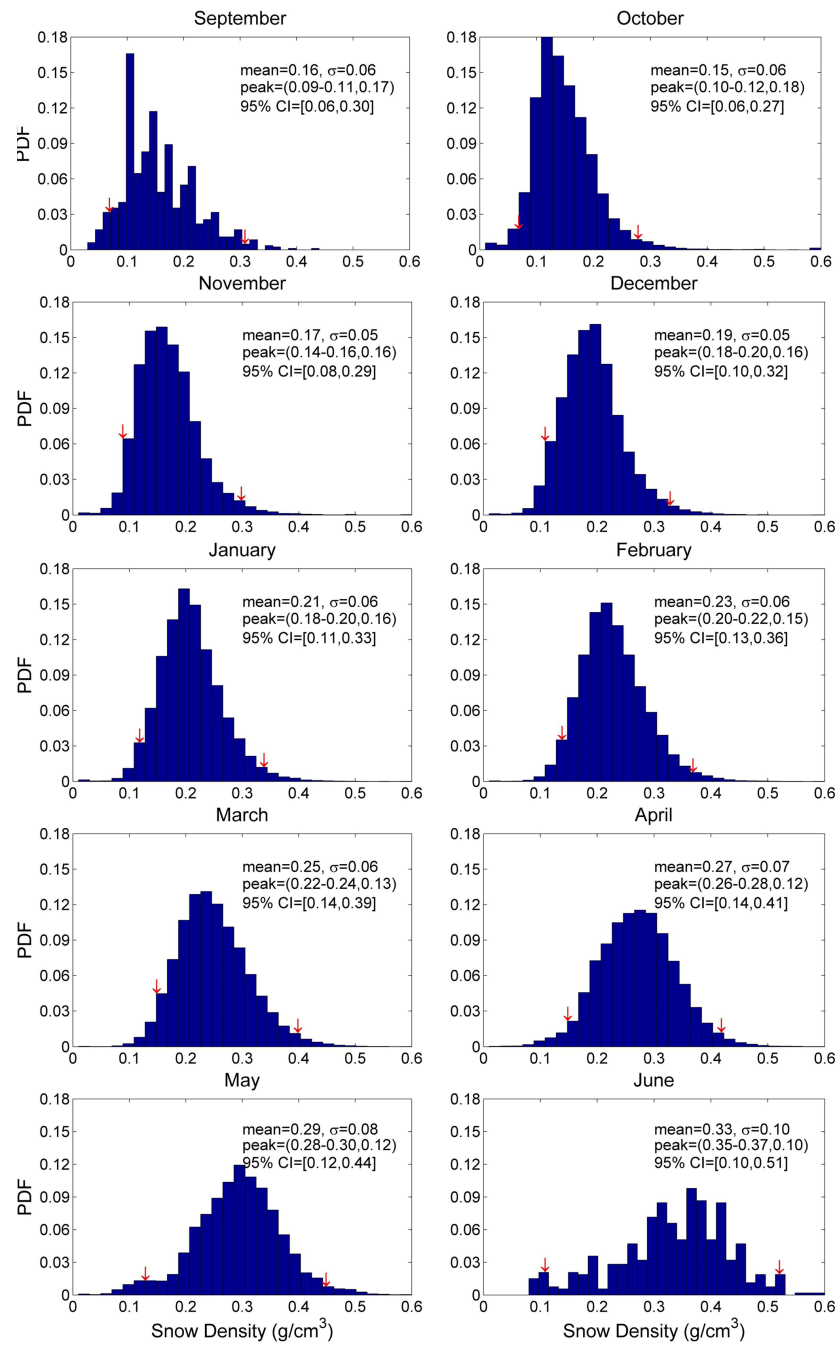

Fig. 12. PDF of monthly snow density. The bar is PDF of snow density; the down arrows represent the bracket $2.5 \%$ and $97.5 \%$ spectrum distribution of snow density. Mean and $\sigma$ represent the calculated mean and standard deviation of all snow density $\left(\mathrm{g} \mathrm{cm}^{-3}\right)$, respectively. Peak stands for the peak PDF of snow density (right) and the corresponding snow density (left); $95 \%$ CI represents the range of snow density at $95 \%$ credibility interval; $\mathrm{CI}$ is the abbreviation for "credibility interval".

clined by $0.005 \mathrm{~g} \mathrm{~cm}^{-3}$ for taiga snow and $0.003 \mathrm{~g} \mathrm{~cm}^{-3}$ for alpine snow, while tundra snow had the largest slope and $R^{2}$, and snow density decreased by about $0.006 \mathrm{~g} \mathrm{~cm}^{-3}$. Although there were 401 sites for prairie snow, these sites had the lowest correlation of snow density and elevation among the four snow classes. Snow density decreased at a rate of approximately $0.003 \mathrm{~g} \mathrm{~cm}^{-3}$ per $100 \mathrm{~m}$ increase in elevation, and $R^{2}$ was only about 0.06 . This indicates that snow density for prairie snow may be more subject to the influence of other factors than to elevation.

The relationships between snow density and latitude for all data and snow classes generally show a positive trend, i.e., 


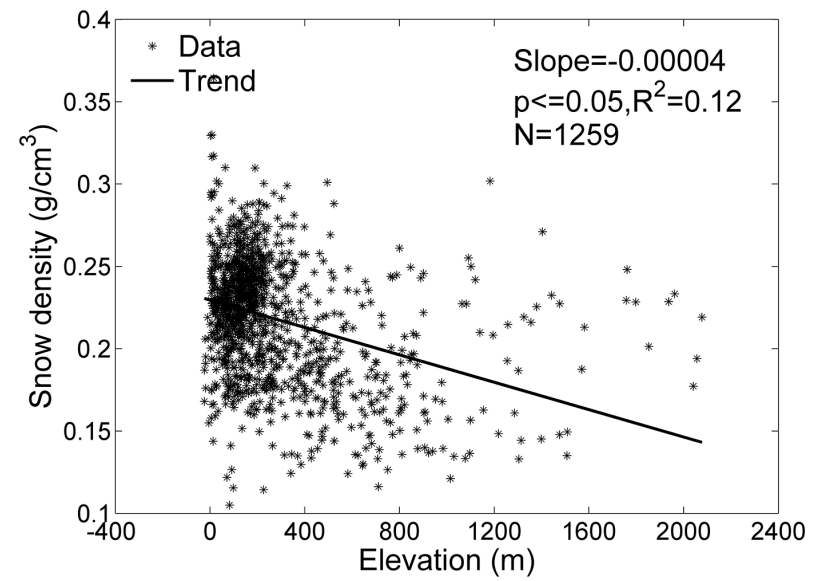

Fig. 13. Snow density changes with elevation for all stations across the former USSR during 1966-2008. Asterisks show the mean snow density of each site; the thick line is a linear regression with the parameters shown on the upper-right corner, where Slope is the slope of -0.004 in $\mathrm{g} \mathrm{cm}^{-3}-100 \mathrm{~m}, p$ is the confidence level for the coefficient estimates, $R^{2}$ is goodness of fit coefficient, and $N$ is the number of stations.

snow density increases with latitude as moving northward (Fig. 15). Although snow densities of all sites increased with latitude ranged from 36 to $78^{\circ} \mathrm{N}$, goodness of fit was only $6 \%$. However, the different impact of latitude on snow density could be found for snow classes. Among snow classes, the highest correlation was found in prairie snow $\left(R^{2}\right.$ was about 0.33 ). With every one degree rise in latitude, snow density increased by $0.0038 \mathrm{~g} \mathrm{~cm}^{-3}$. In contrast, snow density was lowest associated with latitude for tundra snow, and goodness of fit was about $8 \%$. It increased by $0.0017 \mathrm{~g} \mathrm{~cm}^{-3}$ with each one degree rise in latitude.

\section{Discussion}

We compared our results with the past data in the former USSR (Bilello, 1984; Liston and Hiemstra, 2011; Bormann et al., 2013) and North America (McKay and Findlay, 1971; Sturm and Holmgren, 1998; Brown and Mote, 2009; Sturm et al., 2010). We found that they were basically consistent with the past Russian results, which were both of the values by observed (Bilello, 1984; Bormann et al., 2013) and simulated (Liston and Hiemstra, 2011), some of density values from this study were even larger than results from previous studies. However, snow densities from this study were lower than values of snow density from North America. Possible explanations can be summarized as follows:

1. The former USSR has overall lower snow densities than in North America. Bilello (1984) compared the data observed over the former USSR and the northern North America, in which there were much similar winter climatic regimes. The results showed that mean snow densities in the former USSR were lower than the data from North America by about 18-27\%.

2. Different measurement method leads to the difference in snow density over the two continents. Generally, the courses are about $300 \mathrm{~m}$ length in North America (http://www.wcc.nrcs.usda.gov/ snowcourse/). However, snow surveys run 1000 to $2000 \mathrm{~m}$ in open terrain and $500 \mathrm{~m}$ in the forest over the former USSR. In addition, snow courses are usually taken near the end or middle of the month and there is one record for each month (one or two records in May and June) in North America (http://www. wcc.nrcs.usda.gov/snowcourse/). However, the routine snow surveys run every 10 days in the cold season and every 5 days during snowmelt, this means that snow density is measured three times in one month at least in the former USSR. We averaged snow densities and then got the monthly mean for each site, which may lead to lower density in the former USSR.

3. Meteorological condition differences. Compared with results in Brown and Mote (2009; Table 3), monthly mean snow density were $15 \%$ lower for tundra snow and $38 \%$ lower for ephemeral snow cover over the former USSR. For tundra snow, most sites in the former USSR located at the south of $60^{\circ} \mathrm{N}$ rather than arctic and subarctic regions. Affected by snow depth, air temperature, and wind speed, snow densities for tundra snow across the former USSR were lower than the values in Canada. The areas were smaller and the number of sites was fewer for ephemeral snow in Canada, the local characteristics may be the major reasons of these differences. Differences of monthly mean snow density mainly appeared in May and June for other snow classes, which were affected by wind speed. In these two months, snow melt with high air temperature. Meanwhile, wind speed in Canada was significantly higher than the former USSR, which compacted snow led to high snow density.

4. Environment differences. Of the 1259 stations across the former USSR, 719 were measured in open field and forest areas. We compared the monthly mean snow densities of the 719 stations in the two environments for snow classes. The results showed that mean snow densities measured in forest range from $8 \%$ to $13 \%$ less than those measured in open field, which were similar to the results of Bilello's (1984). This was because forest canopies played a large sheltering role on snow cover with their branches and leaves (Bright et al., 2013). The high albedo of dense trees in forests can prevent snow cover from solar radiation (Essery et al., 2008). The snow cover under the protection of trees is also less affected by the compaction of wind. Therefore, the low densities in forest areas lower 

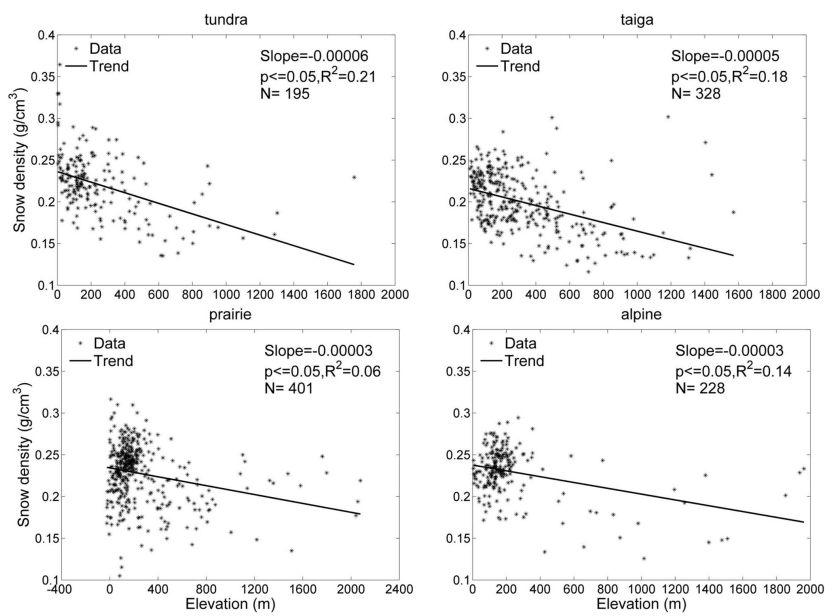

Fig. 14. Snow density changes with elevation for tundra, taiga, prairie, and alpine snow. Asterisks show the mean snow density of each site; the thick line is a linear regression with the parameters shown on the upper-right corner, where Slope is the slope of -0.006 in $\mathrm{g} \mathrm{cm}^{-3}-100 \mathrm{~m}, p$ is the confidence level for the coefficient estimates, $R^{2}$ is the goodness of fit coefficient, and $N$ is the number of stations.

the average snow density over the former USSR as a whole.

Furthermore, the very low percentages of maritime (3\%) and alpine snow cover $(8 \%)$ and fewer stations may not fully represent the climatology of snow density. Those may result station bias away from higher elevation mountain stations, which may be one reason of densities lower than the data in North America. However, to better answer the question why snow over the former USSR was less dense than snow over North America, further investigations are required, especially conducting detailed and comprehensive field measurements.

\section{Conclusions}

This research analyzed bulk density across the former USSR from 1966 to 2008, using data for six snow classes from 1259 stations. We investigated the climatology and variation in monthly mean snow density and the PDF of monthly snow density for each snow class, and researched the connections between snow density, elevation and latitude.

The results show the stations with larger monthly mean snow density were mainly located in the European regions of the former USSR, on the coast of Arctic Russia, and the Kamchatka Peninsula, while the smaller values were found in central Siberia.

There were significant monthly and seasonal changes in snow density across the study area. The maximum and minimum long-term monthly mean snow density was about $0.33 \mathrm{~g} \mathrm{~cm}^{-3}$ in June and $0.14 \mathrm{~g} \mathrm{~cm}^{-3}$ in October, respectively. For the six snow classes, the maximum long-term
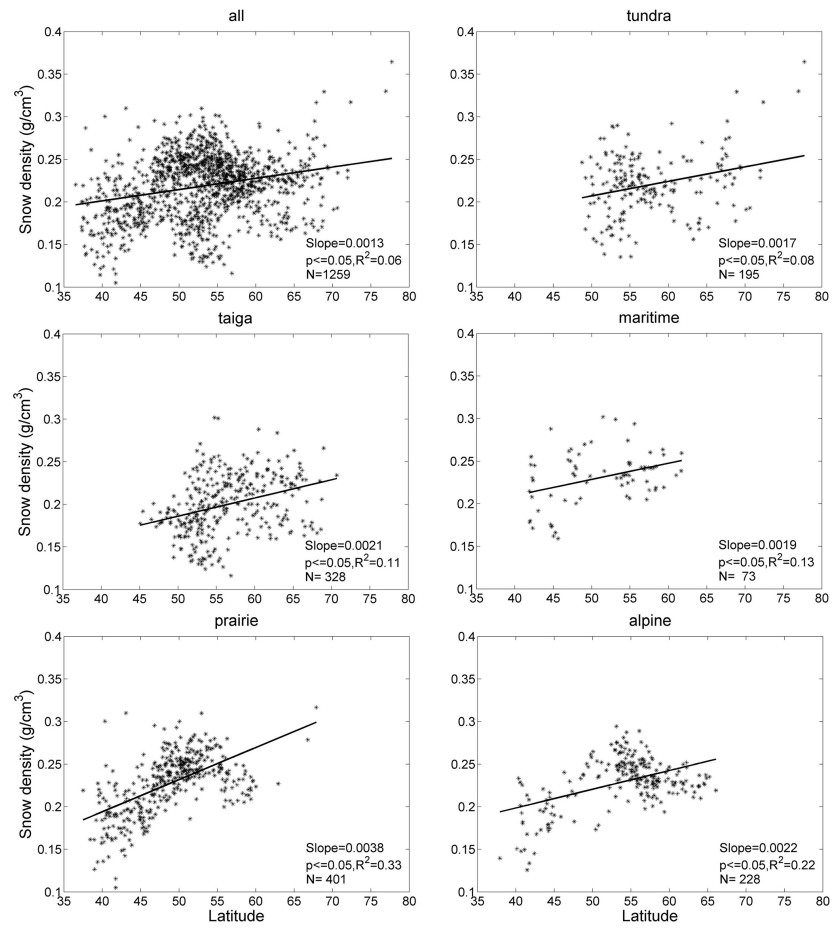

Fig. 15. Snow density changes with latitude. Asterisks show the mean snow density of each site; the thick line is a linear regression with the parameters shown on the upper-right corner, where Slope is the slope of $0.0013 \mathrm{in} \mathrm{g} \mathrm{cm}^{-3}$ per one degree, $p$ is the confidence level for the coefficient estimates, $R^{2}$ is the goodness of fit coefficient, and $N$ is the number of stations.

monthly mean snow density was $0.25 \mathrm{~g} \mathrm{~cm}^{-3}$ for maritime and ephemeral snow, and the minimum value was $0.20 \mathrm{~g} \mathrm{~cm}^{-3}$ for taiga snow. We observed an increasing trend in monthly mean snow density from September to June of the next year, but the rate of increase varied with different snow classes.

The long-term annual mean maximum of monthly snow density mainly appeared in the 1970s, and the minimum values were mostly during 2000s. Sharp changes in annual mean snow density mainly occurred during the autumn months.

From November to January, there were significant decreasing trends in monthly mean snow density and mainly lay in most regions of the European Russia, the south of western and central Siberia. However, the positive trends increased gradually from February to April, which were found in most areas of Russia.

Snow density PDF for all data was fit with a normal distribution. We found that there were similarities in the distribution and the parameter values of snow density for tundra snow and taiga snow, as well as maritime, prairie, and alpine snow. From September to June, monthly snow density showed a dispersed distribution trend. The proportion of snow density at the largest PDF declined, but the corresponding density increased with months. 
There was a high correlation of snow density and elevation for tundra snow, snow density decreased by about $0.006 \mathrm{~g} \mathrm{~cm}^{-3}$ with each $100 \mathrm{~m}$ rise in elevation. And snow density was highly correlated with latitude for prairie snow. It increased by $0.0038 \mathrm{~g} \mathrm{~cm}^{-3}$ with every one degree rise in latitude.

Snow density is one of the most fundamental and important characteristics for estimating and researching snow depth and SWE. In this study, we analyzed the spatiotemporal variability of snow density and the changes of snow density with geographical factors across the former USSR. In future research, we intend to use snow density to investigate SWE, and water resources assessment, in Eurasia.

\section{Supplementary material related to this article is available online at http://www.the-cryosphere.net/8/785/ 2014/tc-8-785-2014-supplement.zip.}

Acknowledgements. We express our gratitude to the researchers who assembled and digitized the snow cover data at sites across the former USSR over a period of years. We would like to thank two reviewers, M. Sturm and S. Dery for their very insightful and constructive comments and suggestions. We wish also to thank R. Brown for his valuable suggestions. This work was funded by the National Key Scientific Research Program of China (2013CBA01802), the Project for Incubation of Specialists in Glaciology and Geocryology of the National Natural Science Foundation of China (J1210003/ J0109) and the National Basic Research Program of China (2012CB955301).

Edited by: R. Kelly

\section{References}

Armstrong, R. L.: Historical Soviet daily snow depth version 2 (HSDSD), Boulder, CO: National Snow and Ice Data Center, CDROM. 2001.

Armstrong, R. L. and Brown, R.: Introduction, in: Snow and climate: Physical Processes, Surface Energy Exchange and Modeling, edited by: Armstrong, R. L. and Brun, E., Cambridge University Press, Cambridge, UK, 1-11, 2008.

Barry, R. G., Armstrong R. L., and Krenke A. N.: An approach to assessing changes in snow cover, an example for the former Soviet Union, Proc. Eastern Snow Conf., 50th Annual Meeting, Montreal, PQ, Canada, 25-33, 8-10 June 1993.

BC Ministry of Environment: Snow survey sampling guide, Water Management Branch, Surface Water Section, Queen's Printer for British Columbia: Victoria, 27 pp., 1981.

Bilello, M. A.: Relationships between climate and regional variations in snow-cover density in North America, CRREL Research Rep., RR 267, 11 pp., 1969.

Bilello, M. A.: Regional and seasonal variations in snow-cover density in the U.S.S.R., CRREL Rep., RR 84-22, 70 pp., 1984.
Bormann, K. J., Westra, S., Evans, J. P., and McCabe, M. F.: Spatial and temporal variability in seasonal snow density, J. Hydrol., 484, 63-73, 2013.

Brown, R. D.: Historical variability in Northern Hemisphere spring snow-covered area, Ann. Glaciol., 25, 340-346, 1997.

Brown, R. D.: Northern Hemisphere snow cover variability and change, 1915-97, J. Climate, 13, 2339-2355, 2000.

Brown, R. D. and Goodison, B. E.: Interannual variability in reconstructed Canadian snow cover, 1915-1992, J. Climate, 9, 12991318, 1996.

Brown, R. D. and Mote, P. W.: The response of Northern Hemisphere snow cover to a changing climate, J. Climate, 22, 2124 2145, 2009.

Bright, R. M., Astrup, R., and Strømman, A. H.: Empirical models of monthly and annual albedo in managed boreal forests of interior Norway, Climate Change, 120, 183-196, 2013.

Bulygina, O. N., Razuvaev, V. N., and Korshunova, N. N.: Changes in snow cover over Northern Eurasia in the last few decades, Environ. Res. Lett., 4, 045026, doi:10.1088/1748-9326/4/4/045026, 2009.

Bulygina, O. N., Groisman, P. Y., Razuvaev, V. N., and Korshunova, N. N.: Changes in snow cover characteristics over Northern Eurasia since 1966, Environ. Res. Lett., 6, 045204, doi:10.1088/17489326/6/4/045204, 2011.

Bulygina, O. N., Razuvaev, V. N., and Korshunova, N. N.: Changes in the wind conditions over Northern Eurasia, AGU Fall Meeting, San Francisco, CA, 3-7 December 2012.

Cohen, J. L., Furtado, J. C., Barlow, M. A., Alexeev, V. A., and Cherry, J. E.: Arctic warming, increasing snow cover and widespread boreal winter cooling, Environ. Res. Lett., 7, 014007, doi:10.1088/1748-9326/7/1/014007, 2012.

Clark, M. P., Serreze, M. C., and Robinson, D. A.: Atmospheric controls on Eurasian snow extent, Int. J. Climatol., 19, 27-40, 1999.

Dai, L. and Che, T.: Spatiotemporal distributions and influences on snow density in China from 1999-2008, Sciences in cold and arid regions, 3, 325-331, 2011.

Essery, R., Pomeroy, J., Ellis, C., and Link, T.: Modelling longwave radiation to snow beneath forest canopies using hemispherical photography or linear regression, Hydrol. Process., 22, 27882800, 2008.

Foster, J., Owe, M., and Rango, A.: Snow cover and temperature relationships in North America and Eurasia, J. Clim. Appl. Meteorol., 22, 460-469, 1983.

Goodison, B. E.: Accuracy of snow samplers for measuring shallow snowpacks: An update, Proc. 35th Annual Eastern Snow Conf., Hanover, NH, 36-49, 2-3 February 1978.

Groisman, P. Y., Karl, T. R., Knight, R. W., and Stenchikov, G. L.: Changes of snow cover, temperature, and radiative heat balance over the Northern Hemisphere, J. Climate, 7, 1633-1656, 1994.

Groisman, P. Y., Knight, R. W., Razuvaev, V. N., Bulygina, O. N., and Karl, T. R.: State of the ground: climatology and changes during the past 69 years over Northern Eurasia for a rarely used measure of snow cover and frozen land, J. Climate, 19, 49334955, 2006.

Gutzler, D. S. and Rosen, R. D.: Interannual variability of wintertime snow cover across the Northern Hemisphere, J. Climate, 5, 1441-1447, 1992. 
Huang, W., Huang, Z., Cui, C., Feng, Z., Li, Q., and Wang, L.: Temporal and spatial distribution of Xinjiang snow density and its consequence, J. Glaciol. Geocryol., 29, 66-72, 2007.

IGOS: Integrated Global Observing Strategy Cryosphere Themem Report - For the monitoring of our environment from space and from earth, WMO/TD-No. 1405, World Meteorological Organization, Geneva.: 100 pp., 2007.

King, J. C., Pomeroy, J. W., Gray, D. M., Fierz, C., Fohn, P., Harding, R. J., Jordan, R. E., Martin, E., and Pluss, C.: Snowatmosphere energy and mass balance, in: Snow and Climate: Physical Processes, Surface Energy Exchange and Modeling, edited by: Armstrong, R. L. and Brun, E., Cambridge University Press, Cambridge, UK, 70-124, 2008.

Kitaev, L., Førland, E., Razuvaev, V., Tveito, O. E., and Krueger, O.: Distribution of snow cover over Northern Eurasia, Nord. Hydrol., 36, 311-319, 2005.

Kuusisto, E.: Snow accumulation and snowmelt in Finland, Publications of the Water Research Institute 55, Valtion painatuskeskus, Helsinki, 149 pp., 1984.

Lazar, B. and Williams, M.: Climate change in western ski areas: potential changes in the timing of wet avalanches and snow quality for the Aspen ski area in the years 2030 and 2100, Cold Reg. Sci. Technol., 51, 219-228, 2008.

Liston, G. E. and Hiemstra, C. A.: The changing cryoshpere: panarctic snow trends (1979-2009), J. Climate, 24, 5691-5712, 2011.

Loginov, V. F. and Volchek, A. A.: Water balance of the river basins over Belarus, Tonpic, Minsk, 160 pp., 2006 (in Russian).

Ma, L. and Qin, D.: Spatial-Temporal characteristics of observed key parameters for snow cover in China during 1957-2009, J. Glaciol. Geocryol., 34, 1-11, 2012.

Margreth, S.: Snow pressure on cableway masts: analysis of damages and design approach, Cold Reg. Sci. Technol., 47, 4-15, 2007.

Matsumura, S. and Yamazaki, K.: Eurasian subarctic summer climate in response to anomalous snow cover, J. Climate, 25, 13051317, 2012.

McKay, G. A. and Findlay B. F.: Variation of snow resources with climate and vegetation in Canada, Proc. 39th Western Snow Conf., Billings, MT, 17-26, 20-22 April 1971.

Peng, S., Piao, S., Ciais, P., Friedlingstein, P., Zhou, L., and Wang, T.: Change in snow phenology and its potential feedback to temperature in the Northern Hemisphere over the last three decades, Environ. Res. Lett., 8, 014008, doi:10.1088/17489326/8/1/014008, 2013.
Robinson, D. A. and Dewey, K. F.: Recent secular variations in the extent of Northern Hemisphere snow cover, Geophys. Res. Lett., 17, 1557-1560, 1990.

Robinson, D. A., Dewey, K. F., and Heim, R. R.: Global snow cover monitoring: an update, B. Am Meteorol. Soc., 74, 1689-1696, 1993.

Robock, A., Mu, M., Vinnikov, K., and Robinson, D.: Land surface conditions over Eurasia and Indian summer monsoon rainfall, J. Geophys. Res., 108, 4131, doi:10.1029/2002JD002286, 2003.

Roebber, P. J., Bruening, S. L., Schultz, D. M., and Cortinas, J. V.: Improving snowfall forecasting by diagnosing snow density, Weather Forecasting, 18, 264-287, 2003.

Speranskaya, N. A: Changes in some elements of the water cycle in the easternmost part of the Baltic Sea Drainage Basin between 1945 and 2010, Oceanologia, 53, 279-292, 2011.

Sturm, M. and Holmgren, J.: Differences in compaction behavior of three climate classes of snow, Ann. Glaciol., 26, 125-130, 1998.

Sturm, M., Holmgren, J., and Liston, G. E.: A seasonal snow cover classification system for local to global applications, J. Climate, 8, 1261-1283, 1995.

Sturm, M., Holmgren, J., and Perovich, D. K.: Winter snow cover on the sea ice of the Arctic Ocean at the Surface Heat Budget of the Arctic Ocean (SHEBA): temporal evolution and spatial variability, J. Geophys. Res., 107, 8047, doi:10.1029/2000JC000400, 2002.

Sturm, M., Taras, B., Liston, G. E., Derksen, C., Jonas, T., and Lea, J.: Estimating snow water equivalent using snow depth data and climate classes, J. Hydrometeorol., 11, 1380-1394, 2010.

Veselov, V. M.: PC archives of the State Data Holding and technology of their organization, Proc. RIHMI-WDC, 170, 16-30, 2002 (in Russian).

Williams, G. P. and Gold, L. W.: Snow density and climate, Transactions, engineering institute of Canada, 2, 91-94, 1958.

Yang, D., Wang, C., Zhang, Y., and Zhang, Z.: Distribution of seasonal snowcover and variation of snow density on the headwaters of Urumqi river basin, Geogr. Res., 11, 86-96, 1992.

Ye, H., Cho, H., and Gustafson, P. E.: The changes in Russian winter snow accumulation during 1936-83 and its spatial patterns, J. Climate, 11, 856-863, 1998. 